\title{
Concepts and Meaning in Medieval Philosophy
}

\section{By Stephen Read}

\begin{abstract}
In his recent study, Concepts, Fodor identifies five nonnegotiable constraints on any theory of concepts. These theses were all shared by the standard medieval theories of concepts. However, those theories were cognitivist, in contrast with Fodor's: concepts are definitions, a form of natural knowledge. The medieval theories were formed under two influences, from Aristotle by way of Boethius, and from Augustine. The tension between them resulted in the Ockhamist notion of a natural language, concepts as signs. Thus conventional signs, spoken and written, signify things in the world by the mediation of concepts which themselves form a language of thought, signifying those things naturally by their similarity. Indeed, later thinkers realised that everything signifies itself and what is like it naturally in a broad sense by means of the concept of its natural likeness.
\end{abstract}

1. Introduction ${ }^{1}$ The medieval theory of signification underpinned the theory of truth, which in turn fed into a theory of inference. The theory of signification describes generally how words relate to things, and how propositions come to mean what they do. But this general description needs a further account of how a particular occurrence of a word in a particular proposition is related to which things in what way. Only then can one say what has to be the case for the proposition to be true, and so determine how truth is preserved in an inference.

For the medievals in whom I am interested, the signification of words and propositions was made possible by their link to concepts. Vocal signs are seen as imposed by custom as marks or signs for concepts, and written signs are in turn marks or signs for vocal signs, and so indirectly for concepts. Concepts, however, signify or conceive a range of objects naturally, not by any conventional imposition. Concepts are formed by abstraction from sensory cognition. These medieval thinkers inherited

\footnotetext{
1 This paper was delivered as the Brigitte Rosenkranz Memorial Lecture at UCLA in 2002, a series of annual lectures in memory of Brigitte Rosenkranz who was a graduate student there. The paper is largely drawn from my contribution to the Introduction to E. P. Bos and S. Read, Concepts: the treatises of Thomas of Cleves and Paul of Gelria: an edition and systematic introduction, Peeters 2001, with permission of Peeters Publishers. It also draws on passages in S. Read, 'How is material supposition possible?', Medieval Philosophy and Theology, 8 (1999), 1-20, with permission of Cambridge University Press.
} 
from Aristotle, and took further, an elaborate and rich theory of cognitive powers which drew from sensation the whole panoply of cognitive awareness. The common sense discovers shape, motion and other aspects of cognition not present in each particular sense-separate experiences are needed to discern motion, and both sight and touch are needed to learn about shape or figure. An estimative or cogitative sense is needed to recognise the hostility of the wolf or the friendliness of the dog, qualities not immediately evident in sensation. Further composition and division is needed to create further concepts, and abstraction to understand generality. But they were empiricists, following Aristotle in believing that all knowledge is derived from the senses. "The mind is a tabula rasa on which nothing is at first written, but can be written" (De Anima 430a1). The innate powers of cognition were manifold and considerable, but no more than is necessary to the empiricist project of obtaining all real knowledge through the senses.

Concepts, therefore, have a natural epistemological relation to the class of things which they signify. To call it "natural" means that the concept is linked by a law-like causal connection to that of which it is a concept, that causal link being explained by the mind's cognitive abilities. Conventional signs, the signs of spoken and written language, in contrast, gain their signification only by being linked by custom and practice to those natural signs. They obtain their signification indirectly, in what Simon Blackburn called a "dog-legged" manner. ${ }^{2}$ Their immediate signification, or what they are primarily attached or subordinate to, is the concept; thereby, their ultimate signification is the range of things to which the concept applies. John Buridan wrote, in the 1350s: "Categorematic words ... signify things by the mediation of their concepts, according to which concepts, or similar ones, they were imposed to signify. So we call the things conceived by those concepts 'ultimate significata' ... but the concepts we call 'immediate significata'."3

2. Concepts in Modern Philosophy What are concepts? Nowadays, just as in medieval times, it is common to identify them as constituents of mental propositions or thoughts. Many mental states have content. They consist in representing something as of some character. That content is specified by a proposition. Just as the sentence

${ }^{2}$ S. Blackburn, Spreading the Word, Oxford 1984, p. 40.

${ }^{3}$ Johannes Buridan, Summulae de Dialectica, tr. G. Klima, New Haven 2001, pp. 253-4; cf. Buridan, Summulae de Suppositionibus, ed. R. van der Lecq, Nijmegen 1998, p. 39: "dictiones categorematicae ... significant res aliquas mediantibus conceptibus earum, secundum quos conceptus vel similitudines impositae fuerunt ad significandum. Sic ergo res illas illis conceptibus conceptas vocamus ultimata significata in proposito. Illos autem conceptus vocamus significata immediata.” 
expressing that proposition has structure and consists of sub-sentential expressions, so it is claimed, propositions can be articulated into components. These propositions have a content which is structured and consists of concepts arranged in a certain conceptual structure, a mental language of concepts.

Concepts are hyperintensional. That is, the criteria of distinctness of concepts is stricter than necessary equivalence. For example, the concepts 'triangle' and 'trilateral' are necessarily equivalent-anything which is trilateral is necessarily triangular and vice versa. Nonetheless, the concepts are distinct. What makes them distinct is that one can believe that the one applies to something without the other. Concepts map out the fine structure of beliefs.

The central opposition in theories of concepts is between those who treat concepts as mental particulars and those who treat them as abstract objects. What unites concepts is their content, and that content consists of a common conceptual structure. Without the mental acts of judging, believing, thinking, there would be no content, no abstract universal. The nominalist urges that concepts have no existence beyond our minds, yet is willing to treat them as a common medium for the articulation and expression of those thoughts. The realist, in contrast, claims priority for the common medium, construing the private thoughts as derivative therefrom.

On the common view, concepts are a kind of particular. They are not only minddependent but also private. We may suggest that different people can share the same concept, since they can think the same thought - that is, their thoughts can have the same content. But all these terms equivocate between a private and a public reference. Each of us has his or her own thoughts and beliefs, and we make our own judgments; we speak loosely when we say that we share and communicate these thoughts, that we can have the same beliefs, and that we make the same judgments.

The hardest question is how a concept is related to its instances, to objects. Again, the popular view grounds this relation in the elaboration of conceptual structure as a mental language. As a language, its constituents are signs, and a concept is related to its instances as a sign to what it signifies. Just as sentences and words are signs, so too mental propositions and concepts are signs, with their own special relation to those objects. What is that relation? Contemporary philosophy of mind is predominantly naturalistic, so that such relations are to be explained in terms of some natural relation, for example, a causal relation. Acquaintance with the object causes the formation of the concept, which then becomes a natural sign for it. An alternative theory claims that the atomic elements of the language of thought are, in some way, innate. Yet that threatens to make their relation to objects mysterious and 
unanalysable, or at least to require an explanation not grounded in experience. Less mysterious is the normal empiricist resort, which is to posit an (innate) faculty of abstraction, which responds to suitable input by eliciting the appropriate concept. Indeed, it is difficult to see how a naturalistic, for example, causal theory, can work without such an inborn ability.

Concepts play an explanatory role. Intentional explanation of a person's actions needs to relate those actions to the intentions and goals to which they are directed. To fill out the intentional nature of the explanation, those actions need to be described in terms which relate to the agent's beliefs and purposes. Thus similar actions can result from dissimilar intents; and different actions can subserve similar purposes. The theory of content articulates this explanatory scheme into a language of the mind. The building blocks of this language are concepts.

Not only is this conceptual language the focus of contemporary research into cognitive science and philosophy of mind. It was also the centre of attention in philosophical thinking in the fourteenth century. There is, indeed, a remarkable parallel between contemporary concerns and theories and medieval conceptions. Perhaps this should not be remarkable - after all, the one preceded the other by some six centuries. But the chain of descent is tangled, and there is assuredly no direct influence of the one on the other. Some may argue that it illustrates the phenomenon of convergence on the truth; others that the same siren voices continue to lead the best thinkers astray.

In a recent study, Concepts, Jerry Fodor presents five theses which together make up what he calls the Representative Theory of Mind, which is to form the bedrock of his theory of concepts. ${ }^{4}$ Concepts are mental particulars with both causal powers and semantic content. The central task he presents is to reveal the link between these two aspects. The first thesis states:

\section{Psychological explanation is typically nomic and is intentional through and} through.

Those who deny this are physicalists, who believe that one day all will be stateable in the language of physics. The medieval conception was definitely on Fodor's side.

\section{2. "Mental representations" are the primitive bearers of intentional content.}

That is, the mental realm is prior to, and explanatory of, the vocal and written realm. The medievals would heartily agree.

${ }^{4}$ Fodor, Concepts: where cognitive science went wrong, Oxford 1998, especially pp. $7 \mathrm{ff}$. 


\section{Thinking is computation.}

Fodor makes much here of Turing's analysis of the notion of effective computation. The crux seems to be, however, that Turing treated mental representations as symbols. We will see in $\S 3$ that this was the revolutionary insight of the thirteenth century which produced the flowering of semantic theory in the fourteenth century.

\section{Meaning is information (more or less).}

The intention is that semantic content follows (somehow) from causal relations, that the content of a concept is a result of its causal relationship to what falls under it. This is what the medievals articulated in their talk of cognitions "naturally signifying" those things which were included in them. Nor were they backward in describing the sensory and intellectual mechanisms by which the cognitions were formed, building on Aristotle's discussion in his De Anima and other biological works.

\section{Whatever distinguishes coextensive concepts is ipso facto "in the head".}

The medievals would agree: if the things signified are the same-where then can the difference lie? It must lie in the cognitions - "in the head". The cognitions have different content, but any abstract notion of content is parasitic on the particular content of particular mental states. So Fodor shares an internalist conception with his medieval precursors.

Fodor's main target in his study is to show that concepts cannot be definitions, for no such concepts could be acquired-or at least, the primitive basis must be atomic and not definitional. He describes his preferred theory as Informational Atomism, where the concept $x$ is not constituted by reference to $x \mathrm{~s}$, but by reference to the response which we humans have to experience of $x$ s. Here he departs radically not just from contemporary cognitive science - as he recognises - but from the medieval picture. For the medieval conception is through and through cognitivist: there is a mechanism by which we acquire the concept of $x$ by experience of $x \mathrm{~s}$. The medievals received this model from Aristotle. It is a classical, empiricist model. For it is worth recognising that the contrast between empiricism and rationalism is really one of degree, not of kind. The former announces that all concepts are acquired; the latter that some are innate. But each has to modify its claim, the empiricist admitting that some "innate" capacity or mechanism (abstraction, induction or whatever) is needed in order to acquire concepts from experience; the rationalist that concepts are only latently there at birth, and their overt recognition is triggered by experience through an appropriate "innate" mechanism. The medievals then are seen as Aristotelians, interested in the mechanism of concept acquisition; Fodor as Platonist, interested in the trigger by which we respond to experience by producing certain concepts to which we are by our nature prone. Fodor describes his theory as explicitly "non-cognitivist": 
a concept $x$ is constituted not (as the definitional theory claims) by what $x$ s have in common, but by our response to $x \mathrm{~s}$ - how $x$ s strike us. Only in this way, he believes, can one explain concept acquisition.

Medieval authors show their rejection of such a theory from the start: "First, we say that concepts are cognitions", writes Thomas of Cleves in the first paragraph of his treatise on Concepts of 1370 or thereabouts. ${ }^{5}$ This is not just a pun: concepts for the medievals really put us in touch with how things are, and constitute a form of knowledge. Moreover, concepts are definitions. The main casualty of denying this, Fodor notes, is analytic connection. If each concept embraces others, either as parts in a literally combinatorial conception, or as constituted by its inferential connections with others, we have an immediate explanation of analytic connections as connections between concepts. On the other hand, if concepts are atomic, connections between them can only be inessential and by association - a position sympathetic to Quine's notorious rejection of analyticity.

In fact, both definitional and atomist theories of concepts admit both complex and unanalysable concepts. Only a holistic theory (the so-called "theory theory" ${ }^{\prime}$ ) can claim that every concept is decomposable. Fodor's so-called "atomist" theory includes molecular concepts like 'white man' which conjoins the possibly atomic concepts 'white' and 'man'. Conversely, the definitional theory cannot maintain that all concepts decompose further, on pain of a regress. The real difference between the two accounts lies in their account of concept acquisition and application: what is the link between the concept $x$ and $x \mathrm{~s}$ ? For Fodor, it is contingent and statistical; for the definitional theory, it is essential - causal and natural.

Thomas of Cleves devotes several pages to discussion of such analytic connections. His analysis suggests a compositional conception of concepts and signs. For example, 'white man' is superior in signification to 'man' for it includes it as part of its signification and so signifies more. But it is inferior to 'man' inferentially [in consequendo] for if there is a white man, there is a man but not vice versa. Signs and concepts are constituted by their signification, which results in their inferential connections. But the inferential model which in more recent times has displaced the compositional model as an articulation of the definitional theory is not in evidence. It is the innate capacity to abstract which makes the compositional and definitional conception of concepts viable.

\footnotetext{
${ }^{5}$ See Bos and Read, Concepts, p. 91: "Dicamus ... primo quod conceptus sunt cognitiones."

${ }^{6}$ Fodor, op. cit., pp. $112 \mathrm{ff}$.
} 
Thomas' treatment of concepts, a model of its time, is thus very different in its epistemological basis from Fodor's information-theoretic account. What they share, however, is also important and extensive. Concepts are mental particulars which provide categories for classification, and they can be composed into thoughts or propositions in such a way that the signification of the composite thought derives from that of its constituents. Concepts are-for us humans, at any rate-learned and public: we all learn them and share them. Fodor describes his five conditions on any theory of concepts as "non-negotiable" (p. 23), so it is not too surprising, perhaps, that he shares them with Paul and Thomas. But it is important, for it shows how contemporary are the medievals' concerns despite the six hundred years which separate us from them.

3. The Boethian and Augustinian Traditions Our conception of concepts and content has, as described in $\$ 2$, an ancestry in the semantic theories and epistemology of the Middle Ages, which in turn were inspired by a passage in Aristotle's De Interpretatione as interpreted by Boethius. Boethius translates Aristotle's remark at 16a3-4 as follows: "spoken [words] are signs (notae) of impressions (passionum) in the soul, and written of spoken"; 7 and in his commentary he elaborates on the relation between written inscription (litterae), the spoken sound (vox), the thought or concept (intellectus) and the thing (res) as follows: "for thing, concept, sound and letter are four: the concept conceives the thing, spoken sounds are signs of the concept, and letters signify the sounds." 8 That is, the letters (in writing) signify the spoken utterance, which in turn designates (a literary variant of 'signify', perhaps, since in the Aristotelian passage they were both 'notae') the concept. ${ }^{9}$ The function of the concept is to act as an intermediary, relating word (spoken and written) and thing, for the concept is an effect or impression (passio) of the thing in the mind. So, if the word signifies the concept by some human conventional imposition, then on hearing the word, we will come naturally to think of the thing. For the mind forms a likeness

\footnotetext{
${ }^{7}$ Boethius, Commentarii in librum Aristotelis Peri Hermeneias: Editio Prima, ed. C. Meiser, Leipzig 1877, p. 36: "sunt ergo ea quae sunt in voce earum quae sunt in anima passionum notae et ea quae scribuntur eorum quae sunt in voce."

8“cum igitur haec sint quattuor: res, intellectus, vox, littera, rem concipit intellectus, intellectum vero voces designant, ipsas vero voces litterae significant” (op. cit., p. 37).

${ }^{9}$ Cf. E.J. Ashworth, 'Jacobus Naveros (fl. ca. 1533) on the question: "Do spoken words signify concepts or things?"', in Logos and Pragma, ed. L.M. De Rijk and H. Braakhuis, Nijmegen 1987, p. 208 n. 10.
} 
(similitudo) of things by a natural capacity. Whereas different peoples, speaking different languages have different words, both written and spoken, the things and the concepts and likenesses by which they conceive them are the same. Boethius' translation of Aristotle continues: "and just as the letters are not the same, neither are the sounds. But they are signs of the same impressions for all, and those in turn are likenesses of the same things." 10 Thus we inhabit the same world and conceive of it the same way, says Aristotle; but we speak (and so write) of it differently.

This is the dominant semantic scheme of the medieval period: words signify concepts, which are likenesses of things in the world. But there is a further suggestion, indeed, a rather different picture, present in Boethius which was only fully elaborated in the thirteenth and fourteenth centuries. A few pages later in his first commentary, Boethius writes: "for the spoken sound and the concept of the thing signify the same thing." 11 The spoken sound signifies both the concept and the thing in the world. When we say 'stone', we signify first the thought or concept of stone and secondarily the stone itself. But in his second commentary, Boethius draws back from this conception, declaring that "although sounds are names of things, but we don't use sounds in this way to signify things, but [to signify] those impressions of things in the soul which are within us." 12 That is, although spoken sounds are names of things and are so by virtue of signifying (by convention) their corresponding concepts (passiones animae), the vocal utterance does not itself in any way signify the thing conceived. For Aristotle had not expressed it in that way.

Equally influential, however, if not more so, was a passage in Augustine's De Doctrina Christiana, where Augustine defines 'sign': "for the sign is something beyond the object which acts on the senses making something else come into thought."13 There is explicit reference to this definition in, for example, the

\footnotetext{
10"et quemadmodum nec litterae omnibus eaedem, sic nec voces eaedem. Quorum autem haec primorum notae, eaedem omnibus passiones animae et quorum hae similitudines, res etiam eaedem" (Boethius, op. cit., p. 36).

11“vox enim et intellectum rei significat et ipsam rem” (Boethius, op. cit., p. 40).

${ }^{12}$ Boethius, Commentarii in librum Aristotelis Peri Hermeneias: Editio Secunda, ed. C. Meiser, Leipzig 1880, p. 41: "licet voces rerum nomina sint, tamen non idcirco utimur vocibus, ut res significemus, sed ut eas quae ex rebus nobis innatae sunt animae passiones."

${ }^{13}$ Augustine, De Doctrina Christiana, ed. R.P.H. Green, Oxford 1995, II I 1, p. 56: "signum est enim res praeter speciem quam ingerit sensibus aliud aliquid ex se faciens in cogitationem venire".
} 
Commentary on Priscian Major ascribed to Robert Kilwardby, ${ }^{14}$ and an implicit one in William of Ockham's Summa Logicae I 1,15 and many other places. However, the Augustinian account differs from Boethius' in two important respects. First, what is signified is the thing - as brought out by Augustine's examples: a footprint is a sign of a foot; and 'cow' signifies cows (op.cit. II X 15) - in both cases because the sign brings the object to mind. Secondly, the sign is required to act on the senses, whether visually, or aurally, or through one of the other senses (cf. II III 4).

The first of these differences takes further the idea that we saw Boethius toyed with in his first commentary, that names signify those things of which they are names. To be sure, they do so through the mediation of a concept or act of mind. That mental act is vital to Augustine's semiotics; but it is not itself signified by the sign. Rather, he speaks of the sign "showing" (demonstrare) what is in the mind: "Conventional signs are those which living things give to each other, in order to show ... their mental state, or what they have sensed or thought." 16 The spoken and written word serves to convey from one mind to another these thoughts or emotions (motus animi). But in the Augustinian account, words signify what they name-the things we talk about.

The question, whether words signify concepts or things, came to the fore in the mid-thirteenth century. Roger Bacon speaks of a great debate on the subject, ${ }^{17}$ as does John Duns Scotus some years later. ${ }^{18}$ Besides the authority of Aristotle via Boethius-and what Aristotle meant is open to interpretation-arguments on each side can be given. For example, if words signified things, would empty names not then become impossible? ${ }^{19}$ On the other hand, when I say that Socrates runs, I mean that Socrates himself runs, not that some image or concept in the mind runs (or

\footnotetext{
${ }^{14}$ K.M. Fredborg et al., 'The Commentary on "Priscianus Maior" ascribed to Robert Kilwardby', Cahiers de l'Institut du Moyen-Age Grec et Latin 15, 1975, p. 1.

${ }^{15}$ G. de Ockham, Summa Logicae, ed. P. Boehner et al., St Bonaventure 1974, p. 9.

${ }^{16}$ Augustine, op cit. (II II 3): "Data vero signa sunt quae sibi quaeque viventia invicem dant ad demonstrandos quantum possunt motus animi sui vel sensa aut intellecta quaelibet”.
}

${ }^{17}$ R. Bacon, De Signis, ed. K.M. Fredborg et al., in 'An inedited part of Roger Bacon's Opus maius: De signis', Traditio 34, 1978, p. 132.

${ }^{18}$ J. Duns Scotus, Ordinatio I d 27 ad $1^{\text {am }}$, ed. Balic, Vatican City 1963, vol. 6, p. 97.

${ }^{19}$ Cf. (ps.-)Kilwardby, ed. Fredborg et al., op.cit., $\$ 2.1 .7$ (p. 67) and $§ 2.1 .9$ (p. 71). 
images running in the mind). ${ }^{20}$ Bacon was only one among many, e.g., Peter of Auvergne, Peter of Cornwall and (ps-)Kilwardby, to extend what is signified from concepts to things. ${ }^{21}$

In tandem with this change in what was signified (things, not concepts) went another, but this time one to which the Augustinian formula was antithetical, in its further requirement that the sign affect the senses in some way. If the word (spoken or written) signifies the thing by virtue of its connection to the concept, what is the right account of the connection of concept and thing? The big idea, which was to produce a huge theoretical development in the fourteenth century, was to suggest that the concept itself is a sign. This was the major original contribution of the thirteenth century, prefigured in Boethius but contrary to the Augustinian inheritance. For it goes directly against Augustine's suggestion that the concept is invoked as intermediary by the operation of the sign on the senses: concepts are insensible; but in the Boethian tradition, although the concept is what is signified by the spoken sound, there is a suggestion that it itself signifies. Boethius writes: "of which therefore there are these four: letters, sounds, concepts, things, and most closely and principally letters signify verbs and names. These in turn principally and truly designate concepts, but in the second place also things. Concepts however are significative only of things." 22

The new conception of the signification of concepts is found as early as the Logica attributed to Lambert of Auxerre (c. 1240). ${ }^{23}$ (Ps-)Kilwardby shows how to square the new conception with the Augustinian requirement. 'Sign' can be taken in two ways, he says. In one way, it is material and sensible, and works by its action on the senses. But in another way, we can think of it in abstraction from its sensible and material aspects - and this is the real subject of the science of signs (op.cit., p. 4). This new departure found its greatest influence in the work of Scotus and Ockham. It also needs to be squared with Aristotle. Scotus writes: "the concept is a natural sign of its object (De Interpretatione ch. 1: impressions [in the soul] are signs of things and naturally

${ }^{20}$ Cf. Bacon, op.cit., p. 133.

${ }^{21}$ See, e.g., Biard, Logique et Théorie du Signe au XIVe Siècle, Paris 1989, pp. 33 ff.

${ }^{22}$ Editio secunda, p. 24: "cui igitur haec sint quattuor, litterae, voces, intellectus, res, proxime quidem et principaliter litterae verba nominaque significant. Haec vero principaliter quidem intellectus, secundo vero loco res quoque designant. Intellectus vero ipsi nihil aliud nisi rerum significativi sunt.”

${ }^{23}$ Logica (Summa Lamberti), ed. F. Alessio, Florence 1971, pp. 205-6. 
so)." ${ }^{24}$ Bacon says much the same: "not every sign is offered to the sense as the usual description of a sign supposes, but something is offered to the intellect alone, as Aristotle observed, who says that impressions in the soul are signs of things." 25 Perhaps misquotation is the only solution, for Aristotle goes on to say categorically that every name is so by convention, since no name is a name naturally: "I said, 'according to convention', for nothing is naturally a name but only when it is a sign."26 The way was now clear for Ockham to open his Summa Logicae with the words: "a concept-term is an concept or impression in the soul signifying or consignifying something naturally". ${ }^{27}$ In doing so, he refers explicitly to Boethius and to Augustine.

4. Mental Language The seeds were sown in Boethius' commentary on Aristotle; they were nurtured and developed in the thirteenth century discussions of the sign; but the full theory of a language of concepts, a mental language, found its most famous, or notorious exponent in the fourteenth century, namely, William of Ockham. A further inspiration for Ockham, and others, was Augustine's image, in his De Trinitate, of an inner language. For Ockham, this finally broke the most important link in the Aristotelian chain, between spoken word and concept. Ockham no longer describes this as a link of signification. Rather, the spoken word is subordinated to the corresponding mental word, and the spoken proposition is subordinated to the mental proposition. The mental word is a concept, a mental item fitted for inclusion in a mental proposition. This is the primary language, what naturally has signification. The spoken word and spoken proposition pick up this signification derivatively and secondarily by corresponding to these mental items: "these concept-terms and propositions composed of them are those mental words which exist only in the mind and cannot be revealed externally, whereas sounds as signs subordinate to them can

${ }^{24}$ J. Duns Scotus, Quaestiones subtillisimae super libros Metaphysicas Aristotelis, lib. VI quaestio III, Opera Omnia, Paris 1893, vol. 7, p. 334a: “intellectio, ut est obiecti, est signum naturale eius (I. Peri Hermeneias: 'passiones sunt notae rerum' et hoc naturaliter).”

\footnotetext{
${ }^{25}$ Bacon attributes the doctrine to Aristotle, too: "non omne signum offertur sensui ut vulgata descriptio signi supponit, sed aliquod soli intellectui offertur, testante Aristotele, qui dicit passiones animae esse signa rerum.” De Signis, ed.cit., p. 82.

${ }^{26}$ Aristotle, De Interpretatione, 16a26. Cf. Boethius, op.cit., Editio prima, p. 50: "secundum placitum vero, quoniam naturaliter nominum nihil est, sed quando fit nota”.

${ }^{27}$ Ockham: "terminus conceptus est intentio seu passio animae aliquid naturaliter significans vel consignificans" (op.cit. I 1).
} 
be pronounced publicly." 28 "It is clear that to every true or false spoken utterance there corresponds a mental proposition composed of concepts." 29

Language is three-fold: written, spoken and mental, but the focus is on mental language. Mental language is common to all, whereas written and spoken languages differ between different peoples, as Aristotle had observed. Mental language provides a "universal semantics", ${ }^{30}$ a natural medium whose properties of signification arise naturally by a causal process. Having a certain concept is not independent of having certain linguistic abilities; it is an ability to exercise those concepts which confers on written and spoken utterances the signification which they have.

The mental language serves to explain many philosophical and semantic phenomena. The presence of the mental proposition distinguishes meaningful utterances from mere parrotting - the parrot who recites "Daisy, daisy" is not accompanying the sounds with the appropriate mental commentary. The mental term or concept serves to disambiguate vocal terms, e.g., 'canis', the much-used example, which can mean 'dog', 'dog-fish' or 'dog-star'. The concept also unites different utterances from different languages, so that, e.g., 'canis' and 'dog' are marks of the same mental item, and so are appropriate translations - the Aristotelian diversity is united in the mental identity. The concept and the mental proposition provide intensionality where the shift to things as what is signified might threaten to remove it. To take a modern example, 'renate' and 'cordate' will for Ockham signify the same things, those creatures which have a kidney and those which have a heart, since they are, we are told, the very same animals. Signification, now that words signify things, not concepts, is extensional. What distinguishes the spoken words 'renate' and 'cordate' is that they are marks of different concepts. What distinguishes the concepts? - their make-up. Simple concepts can be distinguished only in what they are concepts of, i.e., extensionally. So 'renate' and 'cordate' must be complex

\footnotetext{
${ }^{28}$ Ockham, Summa Logicae I 1, ed.cit., p. 7: “isti termini concepti et propositiones ex eis compositae sunt illa verba mentalia quae ... tantum in mente manent et exterius proferri non possunt, quamvis voces tamquam signa subordinata eis pronuntientur exterius ...."

${ }^{29}$ Ockham, Quodlibeta Septem, ed. J. Wey, St Bonaventure 1980, V quaestio 8, p. 509: "Patet ... quod omni orationi vocali verae et falsae correspondet aliqua propositio mentalis composita ex conceptibus."

${ }^{30}$ The phrase is Nuchelmans': see G. Nuchelmans, Late-Scholastic and Humanistic Theories of the Proposition, Amsterdam 1980, p. 4.
} 
concepts. The one contains reference to the concept kidney where the other contains reference to the concept heart. ${ }^{31}$

Once mental language is extended from concepts to mental propositions, new questions arise. What is the grammar of mental language? Ockham, and others, were fascinated by this question. Ockham's mental language contains mental nouns, verbs, adverbs, conjunctions and prepositions. ${ }^{32}$ What are omitted are purely stylistic features of spoken and written language. So number and case are preserved in mental language, for they are essential, but gender and differences only of conjugation or declension, differences of verbal form - of synonymous terms, say - are absent. What is essential is whatever is needed to mark distinctions of truth-value. ${ }^{33}$ Synonymy and ambiguity are absent from the mental realm, but everything necessary for precise expression is retained.

Concepts are what are apt to be part of the mental proposition, ${ }^{34}$ so the mental proposition is, for Ockham, Holcot, Buridan, Marsilius of Inghen, inter alia, a complex. But what provides its unity? This is not a problem specific to the medievals. ${ }^{35}$ But it arises immediately one recognises the propositional complexity of the mental. A mental proposition is not just a list of concepts. What gives that set of concepts its unity? This problem struck Gregory of Rimini so forcefully that he was led to deny complexity and parts to mental propositions: "it seems to me more rational to say that such a mental utterance of whatever sort is not composite in any way." 36 Peter of Ailly followed him, at least for the case of categorical propositions. This doctrine raises its own problems, concerning the relation between concepts and mental propositions if the latter do not contain the former as parts.

\footnotetext{
${ }^{31}$ Cf. Buridan, Sophismata, ed. T.K. Scott, Stuttgart 1977, I conclusio $8^{a}$, pp. 27-8.

${ }^{32}$ See, e.g., Ockham, Summa Logicae I 3.

${ }^{33}$ See, e.g., J. Trentman, 'Ockham on Mental', Mind 79, 1970, p. 589.

${ }^{34}$ Ockham, Summa Logicae I 1, loc.cit.: “terminus conceptus est ... nata esse pars propositionis mentalis".
}

${ }^{35}$ See, e.g., Gaskin, 'Bradley's regress, the copula and the unity of the proposition', The Philosophical Quarterly 45, 1995, 161-80.

\footnotetext{
${ }^{36}$ Gregory of Rimini, Super Primum et Secundum Sententiarum, Venice 1522, repr. St Bonaventure 1955, f. $4^{\text {va: }}$ "videtur mihi rationabilius dici quod talis enuntiatio mentalis cuiuscumque generis mentalium sit non est taliter composita."
} 
Buridan is one of the few who did not follow the new non-Aristotelian path (we think of it as Ockhamist, but it was Ockham's conclusion which permeated Paris, not his works ${ }^{37}$ ), retaining the conception whereby the vocal sign signifies the concept, and only indirectly signifies res extra, by means of the concept. Similarly, the vocal proposition signifies the mental proposition. Paul of Gelria and Thomas of Cleves follow this line, perhaps justifying the description of their semiotic as Buridanian, since Buridan is the most famous upholder of the Aristotelian conception in the fourteenth century. But we still need to ask: what provides the propositional unity to that mental proposition? Buridan wrote: "A mental proposition, however, involves a combination of concepts, and so it presupposes in the mind some simple concepts, to which it adds a complexive concept, by means of which the intellect affirms or denies one of those [presupposed simple] concepts of the other ... That complexive concept is called the copula." 38 Thus the language of concepts also contains a special kind of syncategorematic concept, like 'is', whose function is to bind with the categorematic concepts to form a complex thought, a mental proposition.

Returning to the Augustinians, Ockham and others who take the mental term not as the significate of the vocal term, but as sharing a significate with it, res extra (the external thing), we are left with one further puzzle. What is the significate of the mental proposition as a whole? Indeed, what is the significate of the vocal proposition? A vocal term, like 'man', signifies men, by being subordinate to the concept man which itself naturally signifies men, and 'animal' likewise. But what does 'A man is an animal' signify? For the true Aristotelians, it signifies the mental proposition, but for Ockham and his followers, both term and proposition signify some thing in the world.

There were at least four answers:

1) that it signifies whatever its subject term signifies, i.e., whatever the proposition is about;

\footnotetext{
${ }^{37}$ See Courtenay, 'The reception of Ockham's thought at the University of Paris', in Logique, Ontologie et Théologie au XIVe siècle: preuves et raisons à l'Université de Paris, edd. Z. Kaluza and P. Vignaux, Paris 1984, 43-64.

${ }^{38}$ Buridan, Summulae de Dialectica, tr. Klima, op.cit., p. 24. (The final sentence cited is omitted in Klima's translation.) Cf. J. Pinborg, 'The Summulae, Tractatus I De Introductionibus', p. 87: "propositio autem mentalis consistit in complexione conceptuum, ideo presupponit in mente conceptus simplices et superaddit conceptum complexivum quo intellectus affirmat vel negat unum illorum conceptuum de reliquo ... Ille autem conceptus complexivus dicitur copula.”
} 
2) that it signifies what the categorematic terms signify - so 'A man is an animal', whether written, vocal or mental, signifies men and animals-this was Ockham's view; 39

3) that it signifies some state of things in the world, a propositio in re-a suggestion of Burleigh's; ${ }^{40}$ or

4) that it signifies some complexe significabile (a signifiable complex), as suggested by Wodeham and taken up by Rimini. ${ }^{41}$

5. Concepts and Signification The medievals make the traditional distinction between natural and conventional signification. Natural signs obtain their signification from some dependency or natural relation between sign and significate (thing signified). There are many such relations: natural likeness, identity, contrariety, cause and effect, opposition, relation of part to whole and vice versa, of one part to another, of what contains to what is contained-any real or natural relation of one thing to another. This is a very wide definition, and Thomas of Cleves shows by examples how wide it reaches. For he appeals to natural relations to explain how a term can come to have a secondary signification in addition to its primary signification. Thus 'jar' comes to signify wine, 'lion' to signify a man's strength, 'wolf' to signify cunning, 'dove' to mean simple, 'Job' for patience, 'to plough the sea-shore' (arare litus) to mean labouring uselessly. ${ }^{42}$ His first example is intriguing: he says that 'mouth' (os) comes to signify 'face' (facies). This happens in the phrase 'os gladii', the face (i.e., edge) of the sword. ${ }^{43}$ These are all metaphorical uses, he says. There are also ironical uses, so that 'good' comes to mean 'bad', as in "Oh, what a good boy he is!" The point is that, however the primary signification is come by

\footnotetext{
${ }^{39}$ Nuchelmans, Theories of the Proposition, §12.1.4, p. 201.

${ }^{40}$ Nuchelmans, op.cit., $§ 13.3$, pp. 219 ff.

${ }^{41}$ G. Gál, 'Adam of Wodeham's question on the "complexe significabile" as the immediate object of scientific knowledge', Franciscan Studies 37, 1977, 66-102; Tachau, Vision and Certitude, Leiden 1988, ch. 10; Nuchelmans, op.cit., ch. 14.
}

${ }^{42}$ Cf. Ovid, Tristia 5 IV 48: “nec sinet ille tuos litus arare boves”; cf. Heroides V 116.

\footnotetext{
${ }^{43}$ The phrase occurs several times in the Vulgate, e.g., Luke 21, 24: "and they fell to the edge (face, mouth) of the sword (et cadent in ore gladii)". See also Deuteronomy 13, 15; 20, 13 and 17; Jeremiah 21, 7; and Judith, 2, 16; 7, 17.
} 
(presumably, conventionally, in all these cases), a natural relation between the things signified transfers that primary meaning onto other things related in various waysindeed, practically any.

Conventional signification, in contrast, results from arbitrary custom or agreement in use, and this agreement should be regardless of any natural relation of sign and significate. A natural sign is made by nature; a conventional sign is made by free choice. This agreement in use means that no further arrangement or convention is needed for its signification.

Two corollaries follow from these definitions. First, a natural sign always represents the same thing in the same way for everyone-others things being equal; in contrast, a conventional sign will have different signification depending on the practices and customs in place anywhere. Secondly, error is rare in the case of natural signs but is commonplace with conventional signs. Buridan, Oresme, Marsilius and others all have a question in their De Anima commentaries asking whether the senses can be deceived about their proper objects: they support Aristotle's conclusion (De Anima II, 6: 418a11) that they cannot be-or at least, rarely in the case of universal judgments. But they can be for "special" judgments and judgments of degree. ${ }^{44}$ Conventional signs, writes Paul of Gelria, a follower of Thomas of Cleves, can so strongly mislead that Jews and Saracens err in what they say and write about sacred matters. It is a nice question to ask how the heathens can err in blindness to the

${ }^{44} \mathrm{Cf}$. Buridan, Quaestiones in tres libros De anima II question 11 (ed. P.G. Sobol, John Buridan on the Soul and Sensation: an edition of Book II of his commentary on Aristotle's Book of the Soul, with an introduction and a translation of question 18 on sensible species, Ph.D. thesis, University of Indiana 1984, pp. 167-8): “non videmur decipi quantum ad iudicium generale, sed quantum ad specialia ... Non enim decipimur videntes coloratum iudicando quod coloratum est aliquid vel alicubi. Sed in speciali decipimur iudicando quod est lignum vel lapis, quod est in illo loco vel in isto"; and N. Oresme, Quaestiones in tres libros De anima II question 10 (ed. Marshall, Nicole Oresme's Questiones super libros Aristotelis De anima: a critical edition with introduction and commentary, Ph.D. thesis, Cornell University 1980): “quantum ad iudicium universale [vel] nunquam vel raro est decepcio.” The latter point is expanded in ms. Bruges 477 (which follows Oresme closely: see Marshall, Appendix 2b, p. 785): "quantum ad iudicium speciale sensus bene decipitur circa proprium eius obiectum. Patet nam visus aliquando album iudicet esse rubeum vel nigrum; vel eciam album iudicat esse remissus vel intensius quam in veritate est" - but such a case is set aside as a matter of a common sensible, not proper: "sensus decipitur circa iudicium magis particulare, scilicet iudicando quantum aliquid est album vel in quo gradu. Et racio est quod hoc est sensibile commune: scilicet iudicare de quantitate sive extensiva sive intensiva.” (p. 294) 
shining truth of Christianity - but to suggest it is because of their heathen tongue adds insult to injury. ${ }^{45}$

Thomas Maulfelt, Albert of Saxony and others in the middle and late fourteenth century distinguish among natural signs those signifying naturally and properly (proprie) and those signifying naturally but in a broad sense (communiter): "Some concepts signify themselves naturally in a broad sense and also what is similar to them, as this concept 'man' or similar ones. Some concepts signify themselves naturally and properly, like the concepts quality, being and that sort ... Hence every concept standing in a mental proposition for what it naturally and broadly signifies supposits materially." 46 Concepts of things signify them naturally; they are significations representing them. Other signs do not signify formally by themselves, so they are not significations, but only naturally in the broad sense, or else conventionally. Concepts signify immediately or directly; these signs signifying in the broad sense rely on a further relation of natural and proper signification. An example

\footnotetext{
${ }^{45}$ Note that shortly before Paul was writing, the French Parlement had declared (1374): "Certa sententia seu excommunicatio, quam Judaei inter se vocant Niduy ... Nostra curia inhibet expresse ... Judaeis omnibus ... ne ipsi de cetero in regno nostro Franciae utantur dictis sententiis seu pronuntiationibus de niduy, samatha et de herem inter eos"; and only ten years earlier, King Charles had said: "si aliquis a secta Judaica vellet recedere, spiritu illuminatus divino, ac limitibus erroris derelictus, fidei orthodoxae sacrique baptismatis reciperet sacramenta, quae praehabebat nudaretur omnino ... unde accidebat, quod tales, qui antea se locupletes cernebant, egeni, et quidam ex eis vitam quasi quaererent mendicantium...”. See Charles Dufresne, Dominus Du Cange, Glossarium novum ad scriptores mediae aevi, Paris 1766, vol. III, col. 24.
}

${ }^{46}$ The distinction is found in the Suppositiones treatise of Thomas Maulfelt (Edinburgh ms. 138, f. 63ㄹ): "quidam conceptus significat se communiter naturaliter vel etiam suum simile ut iste conceptus homo vel consimilis. Quidam conceptus significat se naturaliter proprie ut isti conceptus qualitas, ens et huiusmodi ... Omnis igitur conceptus stans in propositione mentali pro isto quod significat naturaliter communiter supponit materialiter. Exemplum ut homo est conceptus anime mee, posito quod sic intelligam. Sed si conceptus propositionis supponit pro isto quod naturaliter proprie representat dicitur supponere personaliter, ut in exemplo qualitas concipitur a me." Cf. anon. ms. BJ 686 f. 22vb: “Thomas de Clivis ponit ... terminus stat pro isto quod significat naturaliter communiter, et sic dicitur supponere materialiter." (See E.P. Bos, Logica modernorum in Prague about 1400, Leiden 2004, Appendix I.1, p. 438.) See also Albert of Saxony, Perutilis Logica, tr. 2 ch. 3, ed. C. Kann, Die Eigenschaften der Termini, Leiden 1994, pp. 174-5. John of Holland contrasts proper natural signification with "improper or general natural signification": Suppositiones, in Four Tracts on Logic, ed. E.P. Bos, Nijmegen 1985, pp. 12-13. 
is the concept whiteness: because of the natural likeness between the species (the form) and the concept, whiteness (albedo) signifies itself naturally but in the broad sense. For a white thing seen signifies itself principally and consequently other coloured things falling under the same concept or intention.

In fact, the same sign can be a natural and a conventional sign for the same things but by different concepts. Take the written sign 'substance', for example. Clearly, it conventionally signifies every substance. Since it is a substance itself, it conventionally signifies itself. But 'substance' also signifies itself naturally in the broad sense, and every sign similar to it. Another example is the spoken term 'utterance' (vox): there is a proper concept common to all the spoken sounds 'utterance' by which 'utterance' signifies those spoken sounds naturally in the broad sense.

So every sign signifies itself — naturally in the broad sense: "every term and indeed anything whatever signifies itself naturally in the broad sense." ${ }^{47}$ In addition, some signs signify themselves conventionally. But in each case, the concepts by which the two significations are enabled are different. The concept of substance is different from the concept of (written) 'substance'; and the concept of utterance is different from the concept of (spoken) 'utterance'.

There is a further distinction. Marsilius of Inghen, following Buridan, distinguishes ultimate from non-ultimate signification:

"It should be noted that the non-ultimate significate of a term is the term itself or one similar or equivalent to it, since first, a term always represents itself and those similar to it to the intellect, whence it points out its ultimate significate to the intellect, namely, the external thing for which such a term is said to stand significatively ... Its ultimate significate is the external thing which such a term signifies if it is spoken or written, and is its natural likeness if it is a mental term." 48 (loc.cit.)

\footnotetext{
${ }^{47}$ See, e.g., Johannes Dorp, Perutile Compendium totius logicae Joannis Buridani cum praeclarissima solertissimi viri Joannis Dorp expositione, Venice 1499, repr. Frankfurt am Main 1965, sig. h4 ${ }^{\mathrm{vb}}$ : "quilibet terminus similiter quelibet res mundi significat se naturaliter communiter"; cf. Peter of Ailly, Concepts and Insolubles, tr. P.V. Spade, Dordrecht 1980, §60, p. 28.

${ }^{48}$ Marsilius of Inghen, Suppositiones, in Treatises on the Properties of Terms, ed. and tr. E. Bos, Reidel 1983, p. 54: "Notandum quod significatum termini non ultimatum vocatur ipse terminusmet aut sibi similis aut equivalens, cum primo semper terminus se ipsum et sibi similem intellectui representet,
} 
Note that not only mental terms but also spoken and written terms have non-ultimate signification.

The notion of broad natural signification is, however, not found in Marsilius. The two notions are brought together, perhaps for the first time, in Peter of Ailly's treatise on Concepts, written only a few years later, in Paris in the early 1370s. ${ }^{49}$ But Peter makes an important new observation. "To signify naturally," he observes, "may be taken in two senses: in a proper sense and in a general sense," (\$32) as Spade renders 'significat naturaliter communiter', which I rendered above as "broad" natural signification. To signify naturally in this broad or general sense is "to represent not by itself, but by means of something else, something to a cognitive power by vitally changing [that power]. And this pertains to any thing whatever. For any thing is by its nature apt to cause a concept of itself in an intellective power ... From this it follows that every thing signifies or is apt to signify itself naturally in a general sense," (§33) i.e., broadly. That everything signifies itself naturally in the broad sense is a crucial observation.

Consequently, corresponding to a spoken sign, like 'homo', there are two concepts. (§63) There is the concept of man which it signifies by convention non-ultimately, which properly and naturally signifies men, who are the ultimate significates of the spoken sign. In addition, there is the concept of the sound 'homo', which naturally and properly signifies the sound 'homo', and by means of which the sound 'man' broadly and naturally signifies itself, and by which it is its own non-ultimate significate. Ailly notes that in the latter case, "some people say it has material supposition". Thus he is aware of Marsilius' view: "when a spoken term ... supposits or is taken for itself, it is taken for a non-ultimate significate." $(\S 67)$

The ultimate significates of 'man' are men; the non-ultimate significates of the term are itself and other similar terms. But we have to be careful here in capturing the medievals' manifold use of the term 'ultimate'. The vocal term 'man' signifies nonultimately (and conventionally) the ultimate concept of man. It signifies ultimately

deinde significatum intellectui ostendit suum ultimatum, scilicet rem extra pro qua talis terminus dicitur stare significative. Exempli gratia: significatum non ultimatum istius termini homo est ipsemet aut sibi similis aut equivalens. Sed significatum ultimatum est ipsa res extra, sicut animal rationale mortale, quia ultimate rem extra significat. Et ideo breviter: significatum ultimatum termini est res extra quam talis terminus ex impositione significat si sit vocalis vel scriptus, et est eius naturalis similitudo si sit terminus mentalis. Significatum non ultimatum dicitur ipsemet terminus vel sibi equivalens."

${ }^{49}$ Tr. Spade, Concepts and Insolubles, op.cit. 
(and conventionally) men. And it signifies itself naturally in the broad sense (naturaliter communiter) and is its non-ultimate significate. Indeed, as we saw, anything whatever signifies itself naturally in the broad sense. Moreover, 'man' also signifies terms similar to it in this way.

These reflections lead to an at first glance surprising consequence: every conventionally significative sign corresponds to at least four significates, namely, two concepts and two (classes of) things conceived by those concepts. For each spoken and written term, as we have seen, corresponds both to a concept embracing its primary (ultimate) signification and to a further concept embracing the class of that term and its natural likenesses. For example, a clock or bell signifies to its hearer the concept of bell, and so itself, and also the concept of time, and so in turn the actual hour of matins, or dinner or singing Compline [completorium $]^{50}$ or for reading. In the case of the vocal term 'man', it is subordinate to the concept naturally embracing the vocal terms 'man', thereby signifies itself and other terms like it, further conventionally corresponds to the concept of man (the natural likeness of men), and finally conventionally signifies its ultimate significates, men like Plato and Socrates.

Here matters become delightfully complex: perhaps it is time for a diagram. (See Figure I.) Here the concept by which a conventionally signifying term naturally signifies in the broad sense (the concept of terms like it) corresponds to the concept by which that term was imposed to signify conventionally, namely, the concept or cognition of those things which the term ultimately signifies. It follows that many mental terms signify conventionally, but not those things of which they are the concept - them they signify naturally and properly, for they are cognitions of them.

${ }^{50}$ Cf. Reinardus Vulpe 3, 557, in Ysengrimus, ed. and tr. J. Mann, Leiden 1987, p. 392: “Carmina nunc stares ad completoria juxta / Qui tardas demens? hinc eremita sali!” 

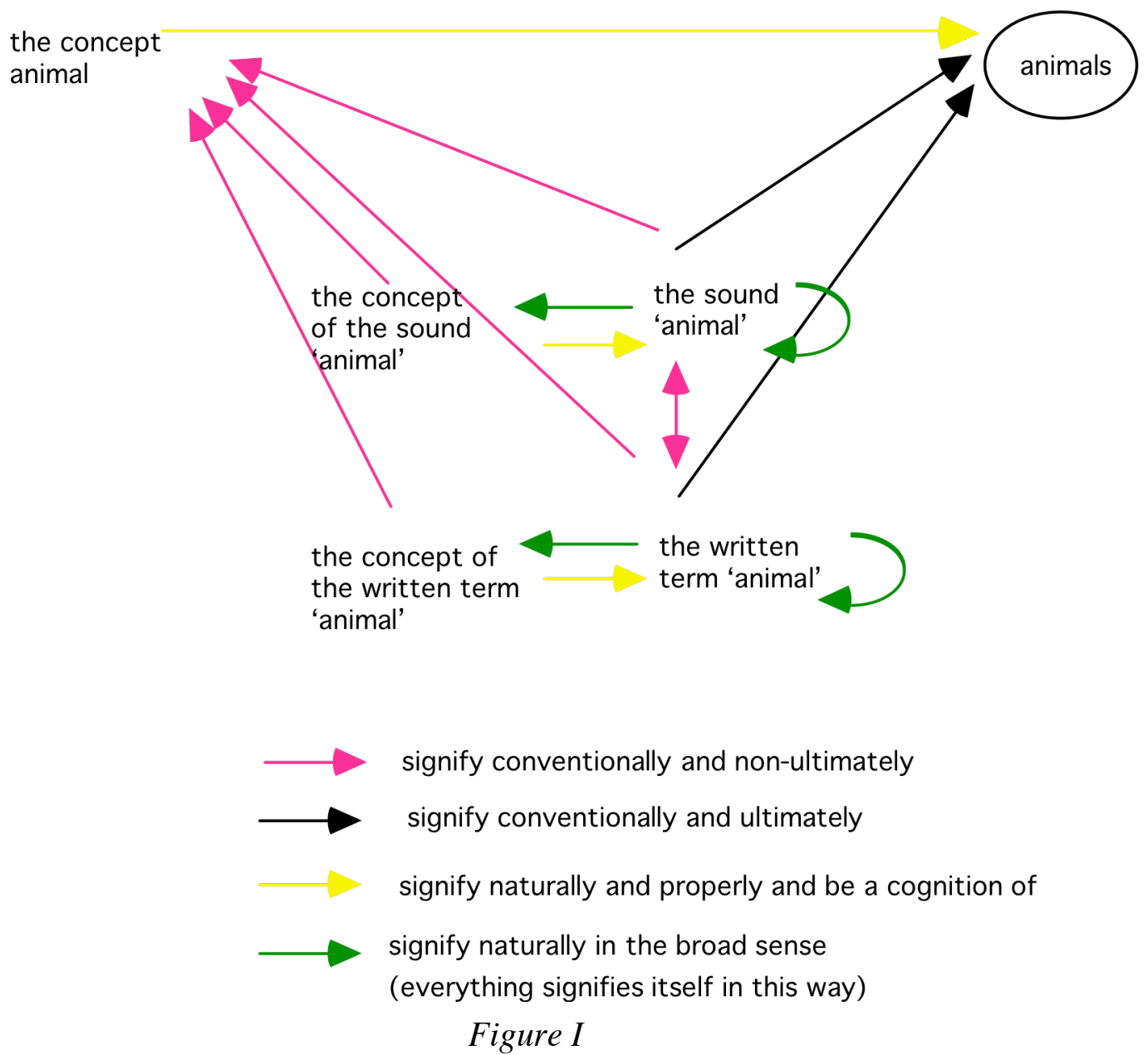

'Animal', for example, ultimately signifies animals (black line) by virtue of its relation (red line) to the concept of animal, which signifies animals naturally and properly (yellow line). But in virtue of what does 'animal' signify itself and its similars? In virtue of a further concept, the concept of the sound 'animal'. In other words, there are two concepts corresponding to the vocal and written terms 'animal', and indeed to every term. Thus to every conventionally signifying term there are four things signified, the two concepts, and the two classes of things conceived by those concepts. In the case of 'sound' (vox), for example, the classes of things signified overlap (in the sound 'sound' itself) - see Figure II.

We find the case of 'man' set out explicitly by Paul of Gelria, in his treatise on concepts of around 1380:

"It should be noted that to every sign signifying by convention there correspond at least four significates, namely, two concepts and two things conceived by these concepts. For example, to this term 'man' signifying by convention there corresponds first [green diagonal], the concept which is a 
natural likeness of this sound 'man', and by means of this it signifies itself and anything naturally similar to itself [green lines], and these are two of its significates which it signifies naturally. Moreover, there corresponds to it [red diagonal] the concept which is a natural likeness [yellow line] of men, which it signifies by convention non-ultimately, and by means of this it ultimately signifies by convention [black line] external things, namely, men, such as Plato and Socrates." 51

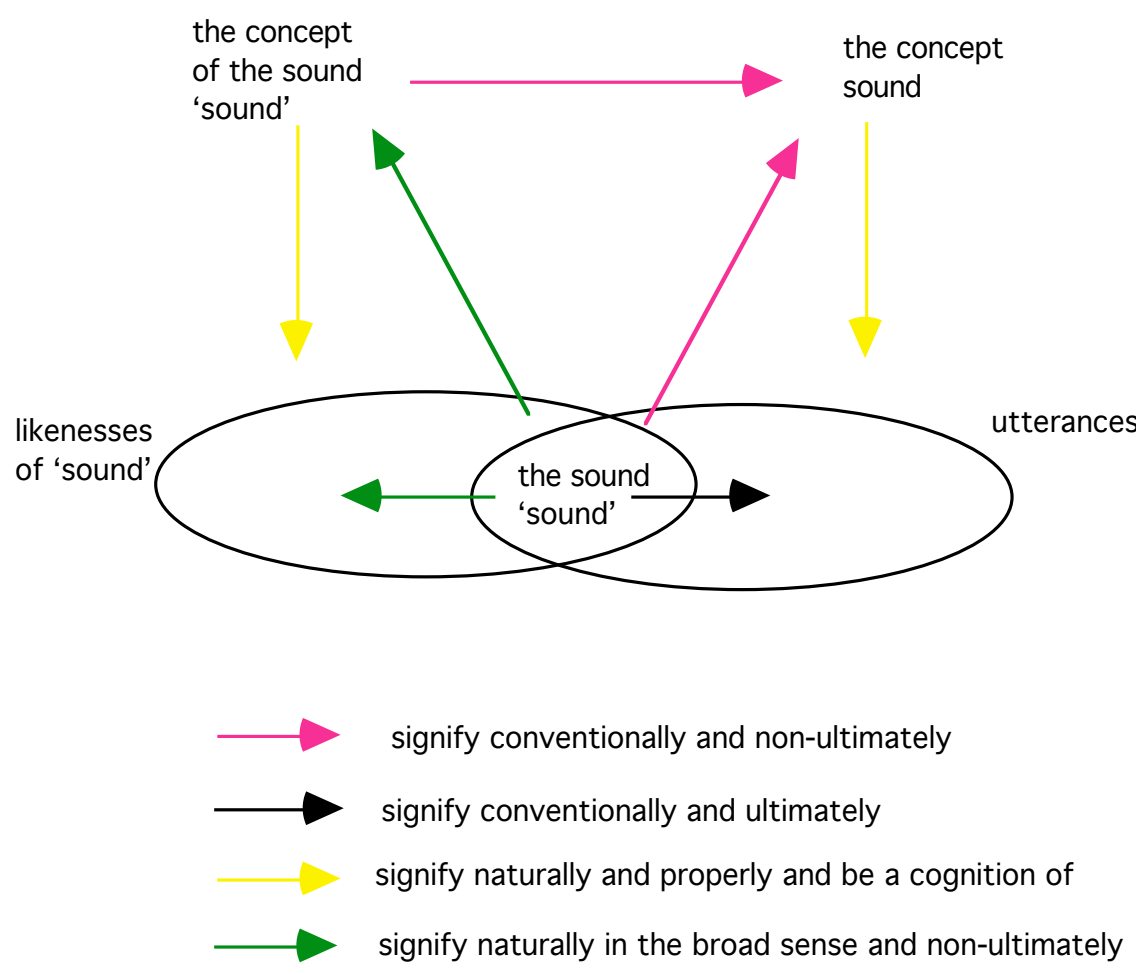

Figure II

\footnotetext{
${ }^{51}$ Paul of Gelria, De Conceptibus, ed. Bos and Read, p. 124: "Notandum quod omni signo ad placitum significanti correspondent ad minus quattuor significata, scilicet duo conceptus et res illis conceptibus concepte. Exemplum: huic termino vocali 'homo' significanti ad placitum correspondet primo conceptus qui est naturalis similitudo huius vocis 'homo', et mediante isto significat se et quodlibet sibi simile naturaliter, et ista sunt duo significata sua que naturaliter significat. Deinde correspondet sibi conceptus qui est naturalis similitudo hominum quam significat ad placitum non ultimate, et mediante isto significat ad placitum ultimate res ad extra, que sunt homines, ut Plato, Sortes.”
} 